\title{
THE 'SOCIAL' POET RESPONSES TO CONTEMPORARY CONCERNS IN THE POETRY OF WORDSWORTH AND JIBANANANDA
}

\section{FIROZE BASU}

Assistant Professor, Department of Management Science and Humanities, MCKV Institute of Engineering, Howrah Kolkata \begin{abstract}
There is an affinity between English poet William Wordsworth (1770-1850) and Bengali poet Jibanananda Das (18991954) in terms of responses to responses to contemporary society and a deep attachment to "native soil" Both poets were instrumental in heralding a new phase in poetic form and content. Wordsworth not only introduced new themes in the Lyrical Ballads but in the Preface to the Lyrical Ballads (1798) advocated new poetic theory which enveloped English poetry for the next two generations. Jibanananda was instrumental in introducing a new poetic sensibility into Bengali Poetry-one that was in tune with contemporary Western Canons of literature. His technique of defamiliarizing the traditional landscape of rural Bengal and the use of unique images created a new poetic voice-rather different from 'Rabindrik' conventions. Both poets were witnesses to considerable political and social turmoil. Wordsworth would experience the manifestations of the Industrial Revolution and the French Revolution. The Indian Freedom Movement and the riots in Bengal (1946) on the eve of Independence would leave an indelible mark on Jibananaanda's poetry.

This endeavour tries to briefly examine affinities in responses to contemporary social change and deep bonds with the native land. There is also a brief study of the conflict between the Rural and the Urban a favourite theme of both poets. Jibanananda's treatise on Bengali poetry 'Why I Write" and "About Poetry' bear a striking resemblance to some issues raised in the Preface to the Lyrical Ballads.
\end{abstract}

KEYWORDS: Kallol Jug, Industrialization, Poetic Diction

Received: Jun 15, 2021; Accepted: Jul 05, 2021; Published: Jul 22, 2021; Paper Id.: IJCMSDEC20214

\section{INTRODUCTION}

\subsection{Contemporary Political Backdrop}

To start very generally, the Romantic concern with more emotional, personal expression is reflective of the lower classes becoming more educated and autonomous.

Literature, as well as other scholarly pursuits, were opened to a greater variety of people, including commoners, as education and ideas spread. Wordsworth's poetry is generally focused on occurrences that ordinary people would be familiar with.

Wordsworth is considered the preeminent poet of nature, though he claimed his main subject was "the Mind of Man—/ My haunt, and the main region of my song." He portrays suffering humanity in many of his poems, showing a variety of causes: poverty, separation, bereavement, neglect.

As education improved and scientific and economic advancements developed, there was also some pushing back and a desire to return to simpler times. 
In "The World is Too Much with Us," Wordsworth seems to argue against consumerism and the desire for worldly possessions. In "Expostulation and Reply" and other poems, he complains about modern education and book learning, telling us instead that much can be learned from nature and our imaginations. Society, in Europe, profited from "the age of reason" and moved toward industrialization. The anxiety of the Romantic poets, Wordsworth in particular, was about the economic challenges facing the rural poor. However, there was some ambiguity in the economic reforms advocated by him.

His views also changed over time. In his youth, Wordsworth supported the cause of the French Revolution and hoped for radical social change. However, over time his views became more conservative. A lot more could be said about Wordsworth and social change. Looking at the beggar poems -- such as "The Old Cumberland Beggar" and "The Reverie of Poor Susan" might be a good place to start.

Jibanananda Das had witnessed an era of severe political disturbances in Bengal in the backdrop of World War 2huge unemployment, financial hardships and a rising communal discord. Premendra Mitra and Subhash Mukhopadhyay, Jibanananda's contemporaries, shared Communist sentiments and identified themselves as representatives of the working classes. Jibanananda does write of the communal riots in Bengal 1946 but there is no definite solution or strong prophetic statement rather an ambiguity. It is impossible to connect Jibanananda with one particular genre or movement of poetry, a fact he acknowledges in the Introduction to the collection of his poems published in 1954 entitled Jibananandaer Shreshto Kobita (The Best Poems of Jibanananda). In the Introduction, Jibanananda observes that he has been identified as a Symbolist poet, a Nature poet and a Surrealist poet by critics He (Jibanananda) goes on to clarify that these 'labels" are for some of his poems, not all.

Jibanananda was writing against the backdrop of the Kallol Yug, was an ardent admirer of Rabindranath and a member of the Progressive Writer's Association (predominantly a leftist organization). But he could never be identified completely with any of these institutions. The leftist poets and critics criticized him for not writing about contemporary issues and being an escapist. Though his later poems would address communal issues they would lack the vigour of propaganda writing of his leftist contemporaries such as Subhash Mukhopadhyay.

Wordsworth and other Romantic poets were vocal against Industrialization. There was a very clear message to turn to Nature for solace, shelter and comfort. Most importantly the message was delivered in clear, precise terms. In his poem "The Tables Turned" there is no ambiguity in the language and the message conveyed through the poem:

Let Nature be your Teacher...

Sweet is the lore which Nature brings;

Our meddling intellect

Mis-shapes the beauteous forms of things:--

We murder to dissect.

Enough of Science and Art;

Close up those barren leaves;

Come forth, and bring with you a heart 
That watches and receives.

We can directly correlate this to Jibanananda's poem 1946-47-"Science is only a collection of a crowd of things, tying us"....

In "Upon Westminster Bridge" Wordsworth describes a serene, quiet city in the early hours of the morning. A bright morning where the elements of Nature-the sun, sky and fields are in their splendour There is also a hint that soon the tranquil atmosphere will be disturbed by the industrial elements of the city coming to life.

This City now doth, like a garment, wear

The beauty of the morning; silent, bare,

Ships, towers, domes, theatres, and temples lie

Open unto the fields, and to the sky;

All bright and glittering in the smokeless air.

Never did sun more beautifully steep

In his first splendour, valley, rock, or hill;

Ne'er saw I, never felt, a calm so deep.

Geoffery Durrant points out that Wordsworth's description of London in The Prelude resembles Milton's description of hell in Paradise Lost. The image of "hell on earth" shown in The Prelude constitutes a place where "men are no longer linked...". He observes that in The Prelude Book VII "Wordsworth succeeds in transforming the raw chaos of the town into a myth of damnation". The author highlights that "The city is presented not only as disorderly, lacking in a real connection between man and man, and superficial, but also as cruel or indifferent". Wordsworth consistently expresses his disappointment with the busy and noisy life of the city in his case the city of London. Jibanananda's disillusionment with the city of Kolkata is expressed through a chilling portrayal of a night in the poem entitled 'Night'

Unscrewing the hydrant the leper licks up water;

Or perhaps the hydrant itself had burst out.

Now the thick of night descends on the city en masse.

A car goes past, coughing like a lout

And shedding restless petrol — as if despite constant caution

Frighteningly into water someone fell,

Three running rickshaws vanished at the last gas lamp

Like magicians at a spell.

And I, having left Phears Lane — in foolhardiness

Walking mile on mile — stopped by 
A wall in Bentinck Street — Tiretta Bazar,

In a wind peanut-dry.

trans Bhaswati Chakroborty

M.H.Abrams asserts that "although Wordsworth sang of joy and love, he did not avert his eyes from anguish or evil, but often represents a "dark world". He also says that "Wordsworth is pre-eminently the poet of solitude but at the same time no poet is more emphatically the poet of community". Wordsworth experienced (during his stay in London) the sudden transition from the moral and agricultural society to an industrial society with its challenges,

The contradictory nature of village and city is a recurrent theme in Jibanananda's poems and short stories. In the poem "Said That Aswattha Tree" the old Aswatta tree of the village makes a plea to those leaving for the city to come back and not be tempted by the promises of the city life-

Said the aswattha tree slowly: "Which way are you headed, Where do you want to go?

We've all been neighbors so long, so very, very close.

Your sun-stained straw huts, they're standing yet.

And here you go forsaking home and lands,

Heading where what path-1 have no idea.

You've wrapped up your belongings, even the broken bowls, that leaky pot.

Now, where are you set on going? "Not fifty years have passed, why, it seems just yesterday Your grandfathers, fathers, uncles - yes, I remember them well. Here on the edge of these very fields they bought land, built their straw huts...

"You won't stay any longer? Which may are you headed?

I suppose there's greater peace somewhere else-more hope? A deeper sense of life, I suppose? And that's why you'll go there to build your huts of hope.

But, no matter where you go, life itself does not change.

Trans Clinton B. Seely in A poet Apart

The short story "The Tale of Village and City" articulates this eternal conflict between the city and the village life.

The story revolves around Prakash, his wife Shachi, and the friend of their youth. Somen. Prakash is the epitome of the successful city elite, rich and powerful. Somen is a bohemian who always reminds Shachi of the simple village life. Jibanananda deftly portrays Shachi's attraction towards Somen as an attraction for the uncomplicated village life.

'We have wrung out the value of this long-lived world," Jibanananda announces in the poem "1946-47", a long poem about partition. "There's no place for the soul in the world/today there is no significant knowledge... there's no glimmer of light.... There is only a soundless deathless surrounding darkness." Wordsworth's reaction to the French Revolution his love for England his longing to return to the English countryside echo similar sentiments. Jibanananda's "blessed despair." And Wordsworth's" still, sad music of humanity" can be viewed in a similar vein. 
In the poem "City" Jibanananda writes- "O heart you have seen a lot of big cities"....and concludes by mentioning that they have turned into ashes-the big city London or Kolkata has been a concern with both Wordsworth and Jibanananda both prefer the rural life over the City.

\section{1,2 True Patriots /Nationalism}

The poetry of Wordsworth and Jibanananda is characterized by a deep sense of patriotism-for Wordsworth the English countryside and for Jibanananda it is rural Bengal.

Jibanananda's fascination with Barisal, a part of undivided Bengal can be equated with Wordsworth.s attachment to the Lake District in England. Several of Wordsworth's poems have England as the theme-England as a symbol of shelter and safety.

In the poem " I Travelled among Unknown Men" Wordsworth expresses his deep attachment to England:

I travelled among unknown men,

In lands beyond the sea;

Nor, England! did I know till then

What love I bore to thee.

'Tis past, that melancholy dream!

Nor will I quit thy shore

A second time; for still I seem

To love thee more and more.

Among thy mountains did I feel

The joy of my desire;

And she I cherished turned her wheel

Beside an English fire.

In "London 1802" Wordsworth urges his predecessor, poet John Milton to return to England as a reincarnation to bring back the long lost virtues.

Milton! thou shouldst be living at this hour:

England hath need of thee: she is a fen

Of stagnant waters: altar, sword, and pen,

Fireside, the heroic wealth of hall and bower,

Have forfeited their ancient English dower

Of inward happiness. We are selfish men;

Oh! raise us up, return to us again; 
And give us manners, virtue, freedom, power.

In one of the most celebrated poems "I shall return to this Bengal" Jibanananda announces:

I shall return to this Bengal, in this Dhansiri's bank:

Perhaps not as a man, but myna or fishing-kite;

Or dawn crow, floating on the mist's bosom to alight...

In the shade of this jackfruit tree, in this autumn harvest-land

Or maybe a duck-a young girl's bells on my red feet.... ( trans Choudhuri A Certain Sense)

In another poem 'I have seen the face of Bengal" Jibanananda vividly describes the beauty of rural Bengal;

I have seen the face of Bengal., so the beauty of the earth

I seek no more, waiting in the dark I see

Under the great umbrella- leaf of the fig tree

The daybreak's magpie-robin; all-round, silent massed leaves... trans Sukanta Chaudhuri

Both poets at several times articulate the immortality of the soul. Jibanananda in " A Poem"

"Even after humans die, humanity remains" trans-Seely in Parabaas and in the poem "Dream';

IStill when all light of this world is extinguished

Man will not be there but his dreams will remain

This poem. in its theme, reminds the reader of Wordsworth's "Ode on Intimations of Immortality" where the immortality of the soul is described:

Our birth is but a sleep and a forgetting;

The Soul that rises with us, our life's Star,

Hath had elsewhere its setting

And cometh from afar;

It would however be unfair for readers to limit their assessment of the two poets to one particular theme.

Geoffrey Hartman is of the opinion that "those famous misrepresents of Wordsworth who says he advocates rural nature as a panacea should be condemned to read The Excursion once a day."

\section{Conclusion}

The modern sense of a Romantic poet may be a figure, creatively following the dictates of his inspiration and actively rejecting contemporary diktats The addendum to this would be a loner, a solitary figure criticized and undervalued during his lifetime. This while partially true of Wordsworth would be almost summing up Jibanananda in a nutshell.

Wordsworth's treatment of Nature, use of diction and critical theories have invited criticism. Francis Jeffrey was one of the first critics to examine works of the Lake poets-Wordsworth, Coleridge, and Robert Southey, Wordsworth's 
poetry, in particular. The reviews were unfavourable and stalled public acceptance of the poet for a number of years. To Jeffrey, Wordsworth's poetic innovations were in "open violation of the established laws of poetry." He described Wordsworth's "stylistic simplicity" as "affectation" and that Wordsworth was 'descending too low' in his writing, In the advertisement printed with the Lyrical Ballads Wordsworth had stated that many of his poetic undertakings are not by current preference. The effort to bring within the purview of poetic diction ordinary day-to-day language catering primarily to commoners was viewed with suspicion and ridicule The evaluation in the Edinburgh Review and the second generation of Romantics Byron and Shelley was uncharitable, to say the least. The main criticism levelled at the time was Wordsworth's "plain" diction and his "shifting" political belief.

Hazlitt and Browning were also critical in their estimation. Thomas de Quincey wrote of Wordsworth in 1835 that "Upto 1820 the name of Wordsworth was trampled underfoot; from 1820 to 1830 it was militant; from 1830 to 1835 it has been triumphant." The poet Matthew Arnold and economist John Stuart Mill both identified in Wordsworth's poems a credible note of belief in the essential 'goodness" of Man in an age fraught with doubt and confusion.

Wordsworth's poetry gained acceptance with time and by the 1830s national recognition. Even among contemporary critics, there is ambiguity regarding the estimation of Wordsworth's poems. "The Excursion" according to Annabel Patterson "has a history of disappointing its readers." Brian Bartlett. remarks on Wordsworth's distinct combination of "man's music and nature's music."

Jibanananda, in the annals of Bengali literature, is synonymous as "a solitary" poet and an "autumn' poet" (Autumn being the predominant season in his poems) From being called a 'rhinoceros poet' by critic Sajanikanto Das in the monthly magazine "Saturday Letters" and his poetry called "vulgar" and "misleading" this lonely poet would receive little critical acclaim during his lifetime. JIbanananda was criticized for his use of colloquial words in poetry such as phede/to tear, semij/a type of dress and ghai-harini/female -deer. In his treatise 'Why I Write "Jibanananda states" all are not poets, only some are' poetry" has no greater purpose" "social concerns should enter poetry as a natural selection but write poetry exclusively for social change and upliftment would be a fallacy" (My Translation). Naturally, the question of being' escapist' in his poetry was praised by poets with Marxist sentiments-Subhash Mukhopadhyay and Samar Sen. It was only Buddhadeb Basu, a fellow poet and close acquaintance who offered a generous evaluation. In "An Acre of Green Grass" Buddhadeb recognizes Jibanananda's unique poetic diction and vivid images Though Jibanananda's contemporaries such as Premendra Mitra were appreciative of his poems it was only posthumously that he was truly recognized as the greatest poet in Bengali Literature after Rabindranath, Incidentally, it was Rabindranath who had labelled Jibanananda's poem 'Before Death" "chitrarupamoy"/like a picture in a letter admiring the pictorial quality of his verse. In the 'Sixties the "Krittibas" group of young poets-Sunil Gangopadhyay, Shakti Chattopadhyay, Binoy Mazumder, Saratkumar Mukhopadhyay and Utpalkumar Basu reinvented Jibanananda's poems drawing inspiration from his vivid images and poetic diction.

The poetic journey of Wordsworth and Jibanananda are similar in terms of responses to contemporary society and a deep attachment to "native soil". Contemporary critical evaluation and subsequent public acclaim unite two poets separated by a century and linguistic and geographical barriers.

\section{REFERENES}

1. Durrant, Geoffrey. William Wordsworth. 1969 Cambridge University Press

2. Wordsworth, William. The Poetical Works of Wordsworth. Oxford University Press. London,1960. 
3. Wordsworth, William: Lyrical Ballads. The Wordsworth Trust. 2005.

4. Abrams M.H; The Mirror and the Lamp Romantic Theory and the Critical Tradition Galaxy Books Paperback March 1972

5. Patterson Annabel: Wordsworth's Georgic: Genre and Structure in The Excursion," in The Wordsworth Circle 9, no. 21978 Jstor

6. Bartlett Brian: 'Inscrutable Workmanship": Music and the Metaphor of Music in the Prelude and The Excursion The Wordsworth Circle volume 171986 Jstor

7. Bandopadhaya, Deviprasad : "Kabya Songroho - Jibanananda Das. Collection of Poetry of Jibanananda Das, 1993, Bharbi,13/1 Bankim Chatterjee Street, Kolkata-73.

8. Chaudhuri, Sukanta (ed): "A Certain Sense - Poems by Jibanarianda Das", Translated by Various Hands, 1998, Sahitya Akademi, Kolkatta. 2006

9. Sresta Kobita Selected Poems in Bengali by Jibanananda Das Edited with an introduction and a chronology of his life and works by Deviprasad Bandhopadhyay Published by Sudhanshu Sekhar Dey, Dey's Publishing ISBN 978-81-295-3125-4

10. Seely, Clinton B: A Poet Apart" (A comprehensive literacy biography of Jibanananda Das, 1990, Associated University Press Ltd, USA.

11. Seely Clinton B. "Scent of Sun"(An anthology of ·poems of Jibanananda Das in English translation). 2008

12. Bhattacharya, Sanjoy. Kobi Jibanananda Das. Kolkata: Bharavi Publications 1970

13. Das, Sisir Kumar. Introduction to A Certain Sense. Poems by Jibanananda Das. Translated by various hands and edited by Sukanta Chaudhuri. New Delhi: Sahitya Akedemi, 2000.

14. Basu, Buddhadev. Probondho Sankolon. Kolkata: Dey's Publishing 1982.

15. Das, Jibanananda. Samagra Prabandha edited by Bhumendra Guha.Kolkata:Pratikshan P 16.Chatterjee, Chandak. Three Stories Jibanananda Das (translations from Bengali) Mumbai: Paperwall Publishing 2016.

16. Muhammad, B. M., A. A. Rahimah, and W. C. V. Yew. "Socio-Economic Effects of Industrialization in the Society." Int. J. Environ. Ecol. Fam. Urban Stud. 8.4 : 23-30.

17. Desai, B., and H. Desai. "Assesment of water quality index for ground water of industrialized area of Surat city, Gujarat, India." International Journal of Environment, Ecology, Family and Urban Studies (IJEEFUS) 6.1 : 135-150.

18. Khan, Mohammad Zakir Hossain. "A case study on Occupational health and safety of footwear manufacturing industry." Journal of Business and GeneralManagement 2 : 1-6.

19. Singh, Narender. "Utilization of Plastic Waste to Improve the Properties of Aggregates Using Dry Process." International Journal of Civil Engineering (IJCE) 4.5: 17-24.

20. Understanding Jibanananda's Different Poetic Sensibility-Arunima Ray Moenia 14 (2008), 181-195.ISSN:11372346.https://www.parabaas.com/jd/articles/arunima_poeticsensibility.shtml 


\section{NOTES}

1.Kallol Jug- The Kallol circle was an important group of Bengali poets in the 1930s notably Buddhadeb Basu, Premendra Mitra Sudhindranath Dutta, Amiyo Chakroborty and. Jibanananda Das wrote against established literary conventions and ushered European Modernism into Bengal freely translating the works of Italian French and German writers.

2, Krittibas Group of Bengali Poets- A group of poets united by a Bengali poetry magazine Krittibas. The magazine provided a platform for young Bengali poets of the fifties and sixties in Bengal who challenged established conventions of poetry.

3.Sanibarer Chiti - A magazine of the 1930s Sanjani Kanta Das, the editor would often target contemporary poets. 
